\title{
Fast Analytical Method for Authentication of Chili Powder from Synthetic Dyes Using UV-Vis Spectroscopy in Combination with Chemometrics
}

\author{
Eti Rohaeti ${ }^{1,2}$, Khoirotul Muzayanah', Dewi Anggraeni Septaningsih ${ }^{2}$, and Mohamad Rafi ${ }^{1,2, *}$ \\ ${ }^{1}$ Department of Chemistry, Faculty of Mathematics and Natural Sciences, Bogor Agricultural University, \\ Jl. Tanjung, Kampus IPB Dramaga, Bogor 16680, Indonesia \\ ${ }^{2}$ Tropical Biopharmaca Research Center-Institute of Research and Community Services, Bogor Agricultural University, \\ Jl. Taman Kencana No. 3, Kampus IPB Taman Kencana, Bogor 16128, Indonesia
}

\section{${ }^{*}$ Corresponding author:}

email:mra@apps.ipb.ac.id

Received: June 9, 2018

Accepted: July 23, 2018

DOI: $10.22146 /$ ijc.36297

\begin{abstract}
Chili is widely used in many food products, especially in Indonesia food. Sometimes a synthetic dye, i.e., rhodamine B or red textile dye were found in commercial chili powder. A fast, precise and accurate analytical method is necessary to authenticate chili powders from the two synthetics dye as they can cause a health problem. A combination of UV-Vis spectroscopy and chemometrics (multivariate analysis) were used in this study to detect rhodamine $B$ and red textile dye present in chili powder samples. Authentication of chili powder from the two dyes by principal component analysis (PCA) with absorbance data from the UV-Vis spectra of samples was not able to classify all of the samples into each group (pure and adulterated chili powder). Fortunately, by using principal component analysis-discriminant analysis (PCA-DA), approximately 89 and $86 \%$ of chili samples mixed with rhodamine $B$ and commercial red textile dye were successfully classified into their corresponding group respectively. The combination of $U V$-Vis spectroscopy with PCA-DA could be used for fast authentication of chili powder from rhodamine $B$ and textile dye used in this study.
\end{abstract}

Keywords: authentication; chemometrics; chili; synthetic dyes; UV-Vis spectroscopy

\section{- INTRODUCTION}

Chili is one of the important fruit commodities in Indonesia because widely used as a coloring and flavoring agent in many Indonesian foods. There are two major chili species and sold in every traditional or modern market in Indonesia, namely Capsicum annum L. and C. frustescens L. C. annum has many varieties and in Indonesia big-red chili (C. annum L. var abbreviata), curly-red chili (C. annum L var longum Sendt) and paprika (C. annum L. var grossum) is the best known [12]. Chili is known for their characteristics aroma and pungency taste that makes chili is widely used in many culinary in the world [3].

As an important fruit or spice in Indonesia, the price of chili in the market could change drastically and also easily decay. Therefore, fresh chili is processed into various products such as dried chili or powder so it can be stored longer. In the making of chili powder, sometimes people added other ingredients such as carrots and garlic to gain weight and homogeneity, but the addition will change the color [4]. This color change may be the reason why some producer added a dye to the chili powder, so that still have as their original color. This activity is an example of food fraud, and the incidence rate of food fraud has increased extensively.

The addition of this dye can be a problem itself if there are irresponsible parties by adding an unsafe synthetic dye. An example of harmful synthetic dyestuffs and has been banned is rhodamine B. Rhodamine B mostly use as a dye in paper or textile and very toxic that can cause cancer. Also, commercial textile dyes usually sold in the market could be a potential to be used as a color enhancer for chili powder. Rhodamine B or commercial red textile dye is sometimes found in food products. According to the report of Djarisnawati et al. [4], 63\% of ground chili sold in some traditional market

Eti Rohaeti et al. 
at Jakarta are found to be contaminated by rhodamine B. Also about 4.68\% from 68 samples of ground chili sold in Sleman regency, Special Region of Yogyakarta is contaminated with rhodamine B [5]. Therefore, a precise, accurate and fast analytical method is needed to authenticate chili powder to guarantee the public health.

Detection of the harmful synthetic dyes in a foodstuff will require an analytical method for food safety evaluation. A multicomponent approach such as fingerprint analysis could be used to detect the presence of contamination or adulteration in food [6]. Fingerprint analysis using spectroscopic or chromatographic technique is now commonly used for quality control as they can provide more accurate and realistic information [7]. One of the analytical techniques that can produce the fingerprint spectra pattern is ultraviolet-visible spectroscopy (UV-Vis) [8]. The advantages of this method are fast, cheap, and easy in sample preparation, making it more efficient when it is used as a quality control method [9]. UV-Vis spectroscopy has been widely used in the identification and authentication of food products. Detection of Sudan I-IV dye counterfeits in several spices [10] and sauces [11] has been developed by using UV-Vis spectra combined with multivariate analysis. UV-Vis spectroscopy combined with multivariate analysis also has been used to assess addition of filler juices and water to pomegranate juices [12] and discrimination of four species of Curcuma from Indonesia [13].

The UV-Vis spectra of chili contain very complex information so the interpretation of the data directly for authentication is not easy. Therefore, an aid from chemometrics such as multivariate analysis is needed to help the identification and authentication of the chili sample. In this paper, we combined UV-Vis spectroscopy with principal component analysis (PCA) and discriminant analysis (DA) as the multivariate analysis to build a new fast analytical method for identification and authentication of chili powder. The developed method could be used and successfully authenticate chili from rhodamine $\mathrm{B}$ and commercial red textile dye.

\section{- EXPERIMENTAL SECTION}

\section{Materials}

A total of 50 samples of chili consisting of 22 bigred and 28 curly-red chilies were collected from 25 locations in West Java and Special Capital Region of Jakarta (Table 1). All of the samples were dried and pulverized before the extraction process. Rhodamine B was purchased from Sigma-Aldrich (St Louis, USA) with the purity about $97 \%$, commercial textile dye (red color) was obtained from a traditional market in South Bogor, Bogor, West Java. Methanol p.a. for solvent extraction was obtained from Merck (Darmstadt, Germany).

\section{Procedure}

\section{Sample preparation}

About $10 \mathrm{mg}$ of pure chili powder was weighed and then $10 \mathrm{~mL}$ of methanol was added to the powder. Extraction was carried out using ultrasonicator US-3 $38 \mathrm{KHz}$ (As One, Osaka, Japan) for $60 \mathrm{~min}$. The extracts were filtered and then transferred to a $10 \mathrm{~mL}$ volumetric flask. For mixed samples, we prepared by adding rhodamine B and commercial textile powder to the chili extract solution with the end concentration of each dye about $1,2.5,5 \mu \mathrm{g} / \mathrm{mL}$. These pure extract and adulterated extract solutions were used for UV-Vis spectra measurement.

\section{UV-Vis spectra measurement}

UV-Vis spectra of all samples extract solutions were measured by using 1700 PC UV-Vis spectrophotometer (Shimadzu, Kyoto, Japan). The measurement UV-Vis spectra were made in the range of wavelength from $200-800 \mathrm{~nm}$ with $0.5 \mathrm{~nm}$ interval in 1 $\mathrm{cm}$ quartz cuvette and fast scan speed option. Methanol was used as blank in the measurement of UV-Vis spectra for all sample extract solutions.

\section{Chemometrics analysis}

The authentication method of chili powder from rhodamine B and commercial textile dye was developed by using absorbance data from UV-Vis spectra 
Table 1. Sources of chili samples

\begin{tabular}{lcc}
\hline & \multicolumn{2}{c}{ Number of samples } \\
\cline { 2 - 3 } Sources (subdistrict, regency, province) & Red curling chili & Red Chili \\
\hline Cibeureum, Bogor, West Java & 1 & 1 \\
Leuwiliang, Bogor, West Java & 1 & 1 \\
Bogor Barat, Bogor, West Java & 1 & 2 \\
Bogor Tengah, Bogor, West Java & 1 & 1 \\
Bogor Timur, Bogor, West Java & 1 & 1 \\
Dramaga, Bogor, West Java & 1 & 1 \\
Pancoran Mas, Depok, West Java & 3 & 3 \\
Sukabumi, Sukabumi, West Java & 2 & 1 \\
Cianjur, Cianjur, West Java & 1 & 1 \\
Cipanas, Cianjur, West Java & 1 & 1 \\
Padalarang, Bandung West Java & 1 & 1 \\
Lembang, Bandung, West Java & 1 & 1 \\
Kiaracondong, Bandung, West Java & 3 & - \\
Sumedang Utara, Sumedang, West Java & 1 \\
Rajapolah, Tasikmalaya, West Java & 1 \\
Cipedes, Tasikmalaya, West Java & 1 & 1 \\
Cihideung, Tasikmalaya, West Java & 1 \\
Cikijing, Majalengka, West Java & 1 & - \\
Kuningan, Kuningan, West Java & 1 & 1 \\
Pleret, Cirebon, West Java & 1 & 1 \\
Sumber, Cirebon, West Java & 1 & 1 \\
Arjawinangun, Cirebon, West Java & 1 \\
Senen, Central Jakarta, Special Region of Jakarta & 1 & - \\
Tanah Abang, Central Jakarta, Special Region of Jakarta & 1 \\
\hline Total number & 1 & - \\
\hline & & 1 \\
\hline
\end{tabular}

combined with multivariate analysis. Principal component analysis (PCA) alone or followed by discriminant analysis (DA) were used for classification of pure and adulterated chili powder with rhodamine B and commercial textile dye. XLSTAT software ver. 2012 (Addinsoft, New York, USA) was used for multivariate analysis in this study.

\section{- RESULTS AND DISCUSSION}

\section{UV-Vis Spectra Analysis}

The ultraviolet-visible spectra pattern of methanolic extract big-red chili and curly-red chili showed maximum absorption at a wavelength range $250-300 \mathrm{~nm}$ and 400 $550 \mathrm{~nm}$ (Fig. 1). The contribution of several electronic transitions such as $\pi-\pi^{*}$ (conjugated $C=C$ ), $n-\pi^{*}$ (aromatic

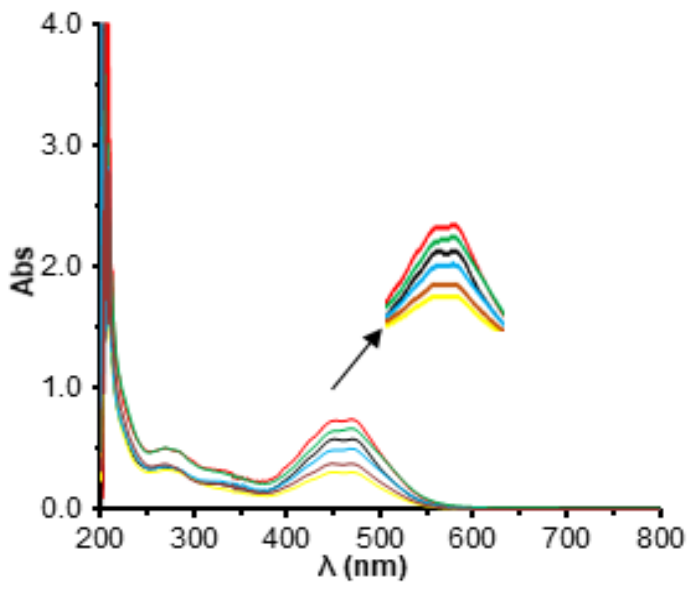

Fig 1. UV-Vis spectra of big-chili methanolic extract from Depok (red line), Majalengka (black line), Cianjur (yellow line), and curly-red chili methanolic extract from Cianjur (green line), Bogor (blue line) and Sumedang (brown line) 
compounds) and $\mathrm{n}-\pi^{\star}(\mathrm{O}-\mathrm{H}$ or $\mathrm{C}=\mathrm{O})$ causes the absorption of UV-Vis in the region 250-550 $\mathrm{nm}$ from the methanolic extract solutions. This typical absorption peaks may be due to the presence of capsaicinoids and carotenoids, respectively. Capsaicinoids are the major compound class present in chili fruit. Capsaicin followed by dihydrocapsaicin, nordihydrocapsaicin, homodihydro capsaicin, and homocapsaicin are an example of chemical components from the capsaicinoids class. Capsaicin and dihydrocapsaicin are the major compound of the capsaicinoids class and account for approximately $90 \%$ of capsaicinoids in chili fruit [14]. Several carotenoids also present in chilies such as capsanthin, capsorubin, capsolutein, violaxanthin, zeaxanthin, $\beta$-carotene and $\beta$ cryptoxanthin [15].

UV-Vis spectra of rhodamine B and commercial red textile dye are shown in Fig. 2. Based on the UV-Vis spectra of rhodamine $\mathrm{B}$, a maximum absorption appears in the 241 and $544 \mathrm{~nm}$ while for commercial textile dye only in the $241 \mathrm{~nm}$. Fig. 3 showed the UV-Vis spectra of mixed curly-red chili extract with the rhodamine B (Fig. 3(a)) and commercial red textile dye (Fig. 3(b)) with the end concentration of the two dyes about $1,2.5$, and 5 $\mu \mathrm{g} / \mathrm{mL}$. In the UV-Vis spectra of adulterated curly-red chili extract with rhodamine B showed an intense peaks at the wavelength $544 \mathrm{~nm}$ indicating the presence of rhodamine $B$. While when curly-red chili extract is added with commercial red textile dye, there is no significant difference in the UV-Vis spectra profile compare to the pure curly-red chili extract only differ in the intensities. So, we can be used the UV-Vis spectra for classification of pure and adulterated curly-red chili from the two dyes used in this study because they give the different spectral profile.

\section{Authentication of Chili Powder from Rhodamine B and Commercial Textile Dye}

A combination of UV-Vis spectra with a multivariate analysis is used in this paper for the authentication of big-red and curly-red chili from rhodamine B and commercial textile dyes (red color). Authentication of raw material is a crucial task in the quality control process of food products to prevent or detect the presence of counterfeit substances. In this study, we used principal component analysis (PCA) alone

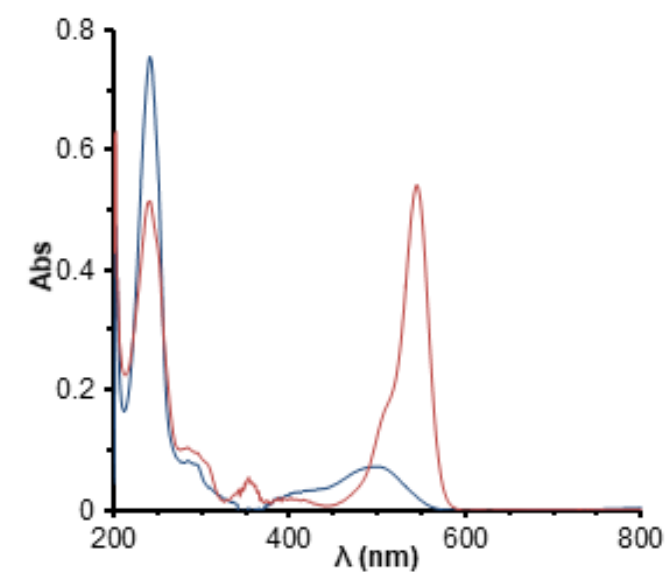

Fig 2. UV-Vis spectra of individual rhodamine B (red line) and commercial red textile dye (blue line)

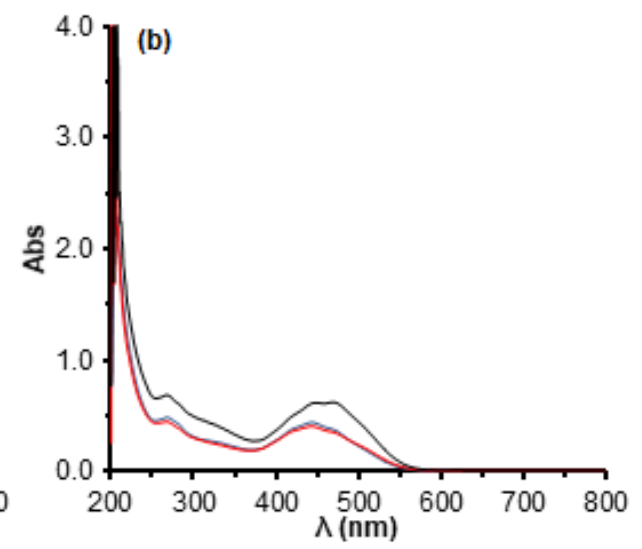

Fig 3. UV-Vis spectra of curly-red chili methanolic extract adulterated with rhodamine B (a) and commercial red textile dye (b) in the concentration of dye at $1 \mu \mathrm{g} / \mathrm{mL}$ (red line), $2.5 \mu \mathrm{g} / \mathrm{mL}$ (blue line), and $5 \mu \mathrm{g} / \mathrm{mL}$ (black line) 


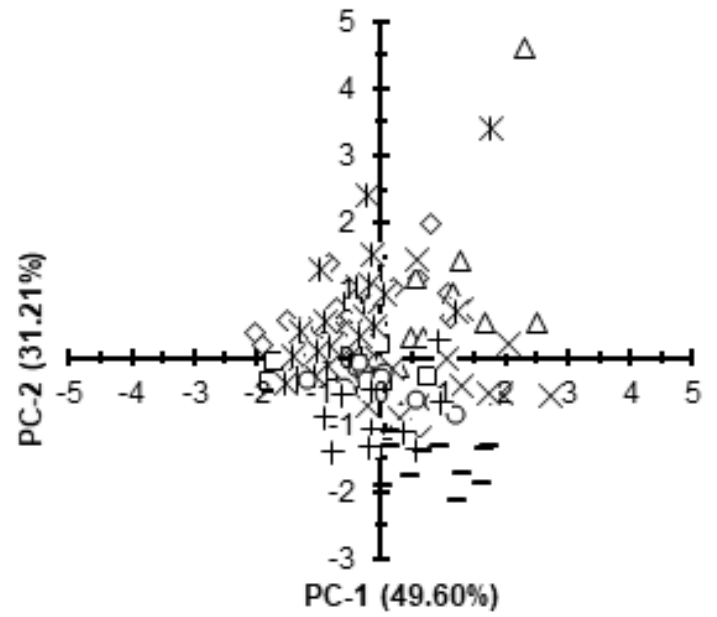

Fig 4. PCA plot of big-red chili ( $\square$ ) adulterated with rhodamine B at the concentration $1 \mu \mathrm{g} / \mathrm{mL}(\diamond) 2.5 \mu \mathrm{g} / \mathrm{mL}$ $(\Delta)$ and $5 \mu \mathrm{g} / \mathrm{mL}(\times)$; curly-red chili $(*)$ adulterated with rhodamine $B$ at the concentration $1 \mu \mathrm{g} / \mathrm{mL}(-), 2.5 \mu \mathrm{g} / \mathrm{mL}$ $(+)$ and $5 \mu \mathrm{g} / \mathrm{mL}(\mathrm{O})$

or followed by discriminant analysis (DA) to build an authentication method of chili powder.

PCA is a well-known multivariate analysis and work by transforming the original variables into new uncorrelated variables called principal components (PCs) with each PC is a linear combination of the observed variables. The $\mathrm{PC}$ obtain still retain the original information of all the data. The first two PCs commonly used and being the most useful in the analysis because they contain the most variations in the data. Similarities among the samples will observe when the PCs values are closer to each other. PCA commonly used for visualization of data groupings, initial evaluation of similarities between groups or classes, and find the factor or pattern observed through correlation with chemical or physical-chemical properties [16].

In this study, about 122 samples (50 pure chili extract and 72 adulterated chilies) was measured for their UV-Vis spectra in the range of wavelength between 200$800 \mathrm{~nm}$ with an interval of $0.5 \mathrm{~nm}$. From these UV-Vis spectra, we will have 1201 absorbance data for each sample. Fig. 4 showed the PCA plot from the two initial PC which explains $80.81 \%$ of the total variance (PC- $1=$ $49.60 \%$, PC-2 $=31.21 \%$ ) was obtained for chili extract

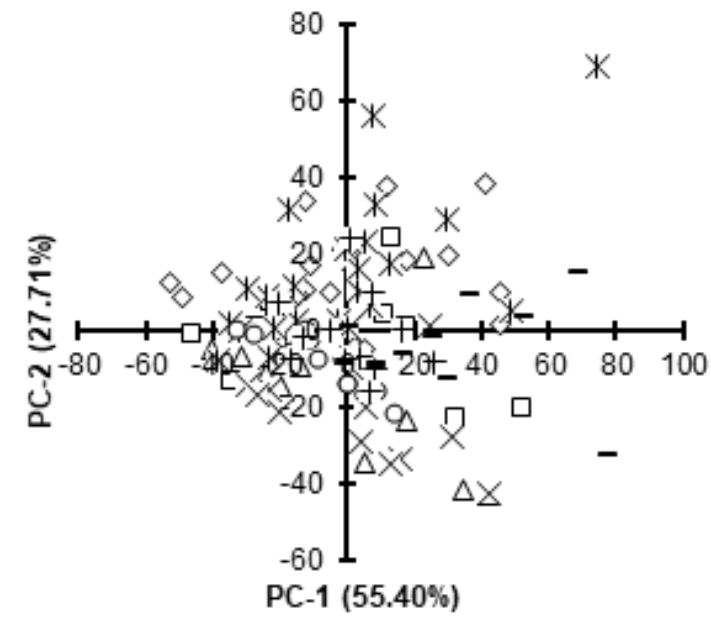

Fig 5. PCA plot of big-red chili ( $\square$ ) adulterated with commercial red textile dye at the concentration $1 \mu \mathrm{g} / \mathrm{mL}$ $(\diamond) 2.5 \mu \mathrm{g} / \mathrm{mL}(\Delta)$ and $5 \mu \mathrm{g} / \mathrm{mL}(\times)$; curly-red chili $(*)$ adulterated with commercial red textile dye at the concentration $1 \mu \mathrm{g} / \mathrm{mL}(-), 2.5 \mu \mathrm{g} / \mathrm{mL}(+)$ and $5 \mu \mathrm{g} / \mathrm{mL}$ (०)

mixed with rhodamine B. While when chili extract mixed with commercial red textile dye, PCA plot from the first two PCs explain $83.11 \%$ of the total variance $(\mathrm{PC}-1=55.40 \%, \mathrm{PC}-2=27.71 \%)$ (Fig. 5). Based on the PCA plot, the pure and adulterated chili could not be distinguished into their groups because the characteristics of the spectra are not so different from each other. Therefore we further used discriminant analysis to classify the samples.

Discriminant analysis (DA) will work by making a discriminant function (DF) for each group by finding a linear combination of the data that will provide the separation of two or more groups of observations [17]. The UV-Vis spectra will contain much information and correlated each other as a result of absorption of all chemical components in the sample. As we know, this condition makes DA could not be used directly to the absorbance data matrix from the UV-Vis spectra because DA will work effectively when the number of samples is more than the number of variables. So, the number of variables used must be reduced before analyzed with DA. PCA was used to reduce the number of variables from the initial data matrix and selected PC's as variable in DA was chosen with Kaiser criterion [18]. 


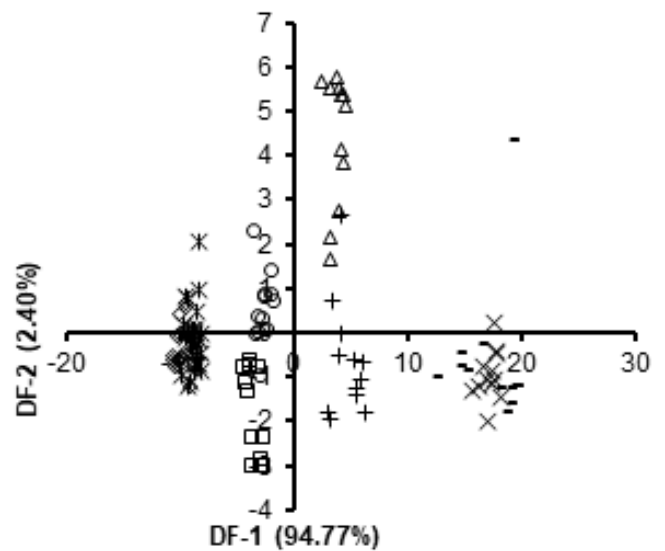

Fig 6. DA plot of big-red chili $(\diamond)$ adulterated with rhodamine B at the concentration $1 \mu \mathrm{g} / \mathrm{mL}(\square), 2.5 \mu \mathrm{g} / \mathrm{mL}$ $(\Delta)$ and $5 \mu \mathrm{g} / \mathrm{mL}(\times)$; curly-red chili $(*)$ adulterated with rhodamine $B$ at the concentration $1 \mu \mathrm{g} / \mathrm{mL}(\circ), 2.5 \mu \mathrm{g} / \mathrm{mL}$ $(+)$, and $5 \mu \mathrm{g} / \mathrm{mL}(-)$

In Kaiser criterion, $\mathrm{PC}$ with the eigenvalue greater than 1 is used in DA. We have selected 9 PCs using this criterion to build an authentication model of chili powder for the two dyes used in this work.

By using the 9 PCs from PCA, we have obtained a DA plot (Fig. 6 and 7) from the first two discriminant function (DF) with the total variance about $97.17 \%$ (DF$1=94.77 \%$ and DF-2 $=2.40 \%)$ and $91.74 \%$ (DF-1 $=$ $81.35 \%$ and DF-2 $=10.39 \%$ ) for chili extract adulterated with rhodamine $\mathrm{B}$ and commercial red textile dye, respectively. As can be seen from the DA plot, the separations of each group (pure and adulterated chili with different concentration of dye) are clearer compared to the PCA only. The predictive ability of the authentication model was evaluated using leave-one-out cross-validation (LOOCV) test. About 89 and $86 \%$ of chili samples mixed with rhodamine and commercial red textile dye were correctly classified according to their classes. This result indicated that the 9 PCs used is a good predictor for the authentication of chili powder from the two dyes used in this study even though not all the samples correctly classified with the LOOCV test.

\section{- CONCLUSION}

We have developed a fast analytical method for authentication of chili powder (big-red and curly-red chili) from rhodamine B and commercial red textile dyes

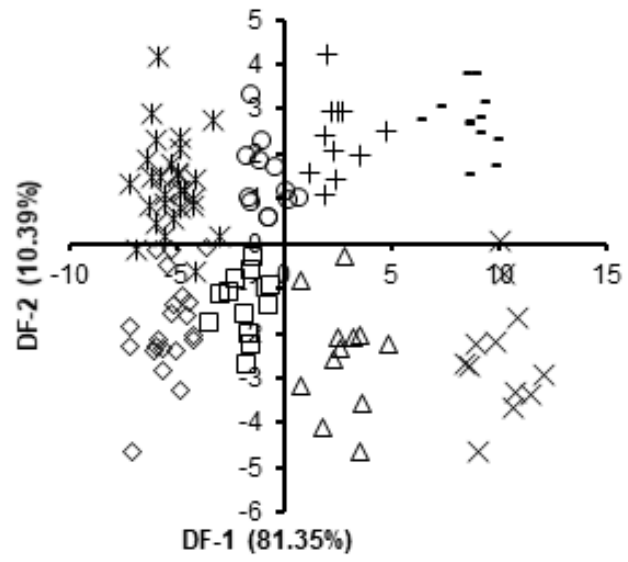

Fig 7. DA plot of big-red chili $(\diamond)$ adulterated with commercial red textile dye at the concentration $1 \mu \mathrm{g} / \mathrm{mL}(\square)$ $2.5 \mu \mathrm{g} / \mathrm{mL}(\Delta)$ and $5 \mu \mathrm{g} / \mathrm{mL}(\times)$; curly-red chili $(*)$ adulterated with commercial red textile dye at the concentration $1 \mu \mathrm{g} / \mathrm{mL}(0), 2.5 \mu \mathrm{g} / \mathrm{mL}(+)$, and $5 \mu \mathrm{g} / \mathrm{mL}(-)$

using UV-Vis spectra combined with. PCA could not able to classify the sample, whereas by using discriminant analysis the samples could classify into their groups. Therefore, the developed method could be applied as an effective and reliable method for authentication of chili powder.

\section{- REFERENCES}

[1] Zhigila, D.A., Rahaman, A.A.A., Kolawole, O.S., and Oladele, F.A., 2014, Fruit morphology as taxonomic features in five varieties of Capsicum annuum L. Solanaceae, J Bot., 2014, 540868.

[2] Octaviani, T., Guntarti, A., and Susanti, H., 2014, Penetapan kadar $\beta$-karoten pada beberapa jenis cabe (Genus Capsicum) dengan metode spektrofotometri tampak, Pharmaciana, 4 (2), 101-109.

[3] Naccarato, A., Furia, E., Sindona, G., and Tagarelli, A., 2016, Multivariate class modeling techniques applied to multielement analysis for the verification of the geographical origin of chili pepper, Food Chem., 206, 217-222.

[4] Djarismawati, Sugiharti, and Nainggolan, R., 2004, Pengetahuan perilaku pedagang cabai merah giling dalam penggunaan rhodamin $\mathrm{B}$ di pasar tradisional di DKI Jakarta, Jurnal Ekologi Kesehatan, 3 (1), 7-12.

[5] Ripaldy, I., Wijanarka, A., and Putriningtyas, N.D., 2017, Analisis kandungan rhodamin B pada cabai 
merah giling di pasar tradisional di kabupaten Sleman, Daerah Istimewa Yogyakarta, Ilmu Gizi Indonesia, 1 (1), 10-18.

[6] Ellis, D.I., Brewster, V.L., Dunn, W.B., Allwood, J.W., Golovanov, A.P., and Godacre, R., 2012, Fingerprinting food: Current technologies for the detection of food adulteration and contamination, Chem. Soc. Rev., 41 (17), 5706-5727.

[7] Purwakusumah, E.D., Rafi, M., Syafitri, U.D., Nurcholis, W., and Adzkiya, M.A.Z., 2014, Identifikasi dan autentikasi jahe merah menggunakan kombinasi spektroskopi FTIR dan kemometrik, Agritech, 34 (1), 82-87.

[8] Casale, M., Oliveri, P., Armanino, C., Lanteri, S., and Forina, M., 2010, NIR and UV-vis spectroscopy, artificial nose and tongue: Comparison of four fingerprinting techniques for the characterisation of Italian red wines, Anal. Chim. Acta, 668 (2), 143-148.

[9] Sánchez, A.M., Carmona, M., Zalacain, A., Carot, J.M., Jabaloyes, J.M., and Alonso, G.L., 2008, Rapid determination of crocetin esters and picrocrocin from saffron spice (Crocus sativus L.) using UVvisible spectrophotometry for quality control, $J$. Agric. Food Chem., 56 (9), 3167-3175.

[10] Di Anibal, C.V., Odena, M., Ruisánchez, I., and Callao, M.P., 2009, Determining the adulteration of spices with Sudan I-II-II-IV dyes by ultravioletvisible spectroscopy and multivariate classification techniques, Talanta, 79 (3), 887-892.

[11] Di Anibal, C.V., Rodriguez, M.S., and Albertengo, L., 2014, UV-Visible spectroscopy and multivariate classification as a screening tool to identify adulteration of culinary spices with Sudan I and blends of Sudan I + IV dyes, Food Anal. Methods, 7 (5), 1090-1096.
[12] Boggia, R., Casolino, M.C., Hysenaj, V., Oliveri, P., and Zunin, P., 2013, A screening method based on UV-visible spectroscopy and multivariate analysis to assess addition of filler juices and water to pomegranate juices, Food Chem., 140 (4), 735-741.

[13] Rafi, M., Jannah, R., Heryanto, R., Kautsar, A., and Septaningsih, D.A., 2018, UV-Vis spectroscopy and chemometrics as a tool for identification and discrimination of four Curcuma species, Int. Food Res. J., 25 (2), 643-648.

[14] González-Zamora, A., Sierra-Campos, E., PérezMorales, R., Vázquez-Vézquez, C., GallegosRobles, M.A., López-Martínez, J.D., and GarcíaHernández, J.L., 2015, Measurement of capsaicinoids in chiltepin hot pepper: A comparison study between spectrophotometric method and high performance liquid chromatography analysis, J. Chem., 2015, 709150.

[15] Topuz, A., and Ozdemir, F., 2007, Assessment of carotenoids, capsaicinoids and ascorbic acid composition of some selected pepper cultivars (Capsicum annuum L.) grown in Turkey, J. Food Compos. Anal., 20 (7), 596-602.

[16] Rohaeti, E., Rafi, M., Syafitri, U.D., and Heryanto R., 2015, Fourier transform infrared spectroscopy combined with chemometrics for discrimination of Curcuma longa, Curcuma xanthorrhiza and Zingiber cassumunar, Spectrochim. Acta, Part A, 137, 1244-1249.

[17] Gad, H.A., El-Ahmady, S.H., Abou-Shoer, M.I., and Al-Azizi, M.M., 2012, Application of chemometrics in authentication of herbal medicines: A review, Phytochem. Anal., 24 (1), 1-24.

[18] Kaiser, H.F., 1960, The application of electronic computers to factor analysis, Educ. Psychol. Meas., 20 (1), 141-151. 